\title{
Nickel isotope fractionation during laterite Ni ore smelting and refining: implications for tracing the sources of $\mathrm{Ni}$ in smelter-affected soils
}

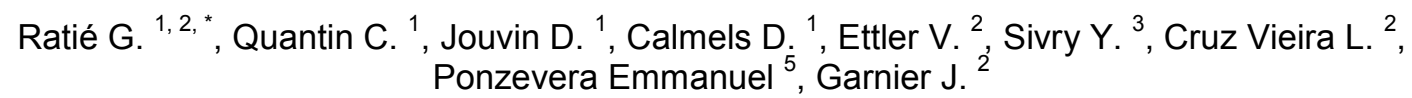

${ }^{1}$ UMR 8148 GEOPS, Université Paris Sud - CNRS, 91405 Cedex, France

${ }^{2}$ UnB, IG/GMP-ICC Centro, Campus Universitario Darcy Ribeiro, 70910-970, Brasilia-DF, Brazil / Laboratoire Mixte International, LMI OCE " Observatoire des changements Environnementaux ", Institut de Recherche pour le Développement / University of Brasilia, Campus Darcy Ribeiro, Brasilia, Brazil

${ }^{3}$ Institute of Geochemistry, Mineralogy and Mineral Resources, Charles University in Prague, Albertov 6, 12843 Prague 2, Czech Republic

${ }^{4}$ Institut de Physique du Globe de Paris, Sorbonne Paris Cité, Univ. Paris Diderot, UMR 7154 CNRS, F75005 Paris, France

${ }^{5}$ IFREMER, Centre de Brest, Unité Géosciences Marines, 29280, Plouzané, France

* Corresponding author : Gildas Ratié, email adress : gildas.ratie@gmail.com

\begin{abstract}
:
Nickel isotope ratios were measured in ores, fly ash, slags and FeNi samples from two metallurgical plants located in the Goiás State, Brazil (Barro Alto, Niquelândia). This allowed investigating the massdependent fractionation of $\mathrm{Ni}$ isotopes during the Ni-laterite ore smelting and refining. Feeding material exhibits a large range of $\delta 60 \mathrm{Ni}$ values (from $0.02 \pm 0.10 \%$ to $0.20 \pm 0.05 \%$, $n=7$ ), explained by the diversity of Ni-bearing phases, and the average of $\delta 60$ Nifeeding materials was found equal to $0.08 \pm$ $0.08 \%$ ( $2 \mathrm{SD}, \mathrm{n}=7)$. Both $\delta 60 \mathrm{Ni}$ values of fly ash $(\delta 60 \mathrm{Ni}=0.07 \pm 0.07 \%, \mathrm{n}=10)$ and final FeNi produced $(0.05 \pm 0.02 \%, n=2)$ were not significantly different from the feeding materials ones. These values are consistent with the very high production yield of the factories. However, smelting slags present the heaviest $\delta 60 \mathrm{Ni}$ values of all the smelter samples, with $\delta 60 \mathrm{Ni}$ ranging from $0.11 \pm 0.05 \%$ o to $0.27 \pm$ $0.05 \%(n=8)$. Soils were also collected near and far from the Niquelândia metallurgical plant, to evaluate the potential of $\mathrm{Ni}$ isotopes for tracing the natural vs anthropogenic $\mathrm{Ni}$ in soils. The $\mathrm{Ni}$ isotopic composition of the non-impacted topsoils developed on ultramafic rocks ranges from $-0.26 \pm 0.09 \%$ to $0.04 \pm 0.05 \%(n=20)$. On the contrary, the Ni isotopic composition of the non-ultramafic topsoils, collected close to the plant, exhibit a large variation of $\delta 60 \mathrm{Ni}$, ranging from $-0.19 \pm 0.13 \%$ up to $0.10 \pm$ $0.05 \%$ o $(n=4)$. This slight but significant enrichment in heavy isotopes highlight the potential impact of smelting activity in the surrounding area, as well as the potential of $\mathrm{Ni}$ isotopes for discerning anthropogenic samples (heavier $\delta 60 \mathrm{Ni}$ values) from natural ones (lighter $\delta 60 \mathrm{Ni}$ values). However, given the global range of published $\delta 60 \mathrm{Ni}$ values (from -1.03 to $2.5 \%$ ) and more particularly those associated to natural weathering of ultramafic rocks (from -0.61 to $0.32 \%$ ), the use of $\mathrm{Ni}$ isotopes for tracing environmental contamination from smelters will remain challenging.
\end{abstract}




\section{Graphical abstract}
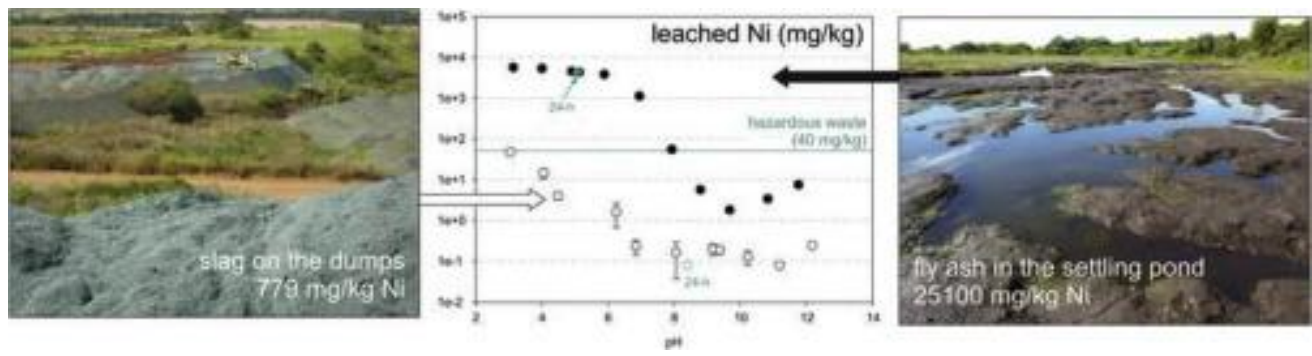

\section{Highlights}

Smelting and refining $\mathrm{Ni}$ ore laterites induce slight $\mathrm{Ni}$ isotope fractionation. $\delta^{60} \mathrm{Ni}$ values of anthropogenic Ni product fall within the range of terrestrial samples. Smelting slags are enriched in $\mathrm{Ni}$ heavy isotopes with respect to soils samples. Use of $\mathrm{Ni}$ isotopes for tracing environmental contamination remains challenging.

Keywords : Nickel, isotope, smelting, refining, source, soil

\section{Introduction}

Nickel is an important metal in modern infrastructure and technology, with major uses in the production of stainless steel $(60 \%$ of the global primary Ni consumption, Nickel Institute, 2013$)$ and alloys and other application such as electroplating or production of rechargeable batteries (Mudd, 2010). It is therefore of major economic importance. The worldwide increasing demand of metals for economic purpose induces intense mining that 
may lead to anthropogenic forcing on the environment. The world nickel production increased from $1,400,000 \mathrm{t}$ to $2,400,000 \mathrm{t}$ over the last ten years (USGS, 2015). For instance, the Chinese stainless steel industry was the main consumer of primary Ni in $2011(521,000 \mathrm{t}$ of primary $\mathrm{Ni}$ ), increasing its $\mathrm{Ni}$ demand by $22 \%$ in one year (USGS, 2011). Economic Ni resources are found either in magmatic sulfide deposits, where the principal ore mineral is pentlandite $\left((\mathrm{FeNi})_{9} \mathrm{~S}_{8}\right)$ (Naldrett et al., 1979; Hoatson et al., 2006), or in laterite-type ores deposits where the main ore minerals are nickeliferous limonite and garnierite (hydrous $\mathrm{Mg}$ $\mathrm{Ni}$ phyllosilicates, e.g. $\left(\mathrm{Mg}, \mathrm{Ni}_{3} \mathrm{Si}_{2} \mathrm{O}_{5}(\mathrm{OH})_{4}\right)$ (Dalvi et al., 2004; Butt \& Cluzel, 2013). Currently, about $1 / 3$ of the primary $\mathrm{Ni}$ is produced by smelting of lateritic ores, which represent $60-70 \%$ of the terrestrial reserves, and is used at $90 \%$ for ferronickel (FeNi) and $10 \%$ for sulfide matte (Crundwell et al., 2011). To meet future demand for $\mathrm{Ni}$, laterite ores are increasingly mined.

The feeding material of laterite smelting corresponds to a mixture of moist saprolitic and lateritic ores derived from the weathering of ultramafic (UM) rock under tropical conditions. Ores developed in such UM rocks contain 0.4 to 3 wt\% Ni (Dalvi et al., 2004; Butt and Cluzel, 2013). In saprolitic ores, Ni is commonly found associated with primary and secondary clay minerals such as serpentine, talc, chlorite and smectite (Colin et al., 1985; Manceau \& Calas, 1985; Gaudin et al., 2004; Gleeson et al., 2004). In some saprolite veins, talc-like and serpentine-like minerals, also known as "garnierite", may contain up to $30 \mathrm{wt} \%$ Ni (Wells et al., 2009; Villanova-de-Benavent et al., 2014). Sepiolite may also contain significant Ni amounts (Gleeson et al., 2004; Villanova-de-Benavent et al., 2014; Ratié et al., 2015). In the lateritic ores, Fe-oxides are the main Ni-bearing minerals (Manceau et al., 2000; Quantin et al., 2002; Dublet et al., 2012 and 2015) and can residually concentrate Ni up to 1 wt. \%. Moreover, in the transition laterite, Mn-oxides can also be significant Ni-scavengers (Fan and Gerson, 2011). Due to the high Fe content of the saprolitic and limonitic ores mixture (up to 40 wt. $\% \mathrm{Fe}_{2} \mathrm{O}_{3}$ ), the smelting product is $\mathrm{FeNi}$, for which typical composition is 20-40\% Ni and 80-60\% Fe, after refining (Crundwell et al., 2011).

The FeNi production from laterite smelting follows four main steps: drying of the feeding material in rotating kiln, calcination with coal, oil or other organic products, reduction in electric furnace and finally, refining of the molten FeNi in an electric furnace (Crundwell et al., 2011). These smelting steps also produce a huge amount of by-products (fly ash, smelting slags and refining slags), which may contain significant amounts of $\mathrm{Ni}$ and other trace metals (see tab. 1). Waste materials are either stored in settling ponds (fly ash) or dumped (slags) or 
partially reprocessed (fly ash). Such disposal sites might have environmental consequences in the vicinity of the smelters, due to the release of $\mathrm{Ni}$ and other metals by leaching and erosion during long-term storage (Ettler et al., 2005). Moreover, the widespread use of Ni in industry is responsible for significant anthropogenic discharge in the environment (Romic \& Romic 2003; Buzier et al. 2011).

The isotopic composition of metals has been shown to constitute an efficient tool to trace anthropogenic contamination in the environment (e.g. Cloquet et al., 2006; Weiss et al., 2008; Chen et al., 2008; Mattielli et al., 2009; Stetson et al., 2009). Isotope fractionation of $\mathrm{Zn}, \mathrm{Cu}, \mathrm{Cd}$ and $\mathrm{Hg}$ has been observed during roasting, smelting and refining processes (Mattielli et al., 2006; Sivry et al., 2008; Sonke et al., 2008; Shiel et al., 2010; Gray et al., 2013). For instance, the $\mathrm{Zn}$ remaining in metallurgical tailings is significantly fractionated relative to $\mathrm{Zn}$ ore, allowing to trace anthropogenic $\mathrm{Zn}$ contamination in the Lot watershed, France (Sivry et al., 2008). Zinc isotopes have also been used to evidence the imprint of smelting activities on the surrounding environment through atmospheric deposition of smelting residues (Sonke et al., 2008).

This article aims at determining nickel isotopic fractionation associated with smelting processes of Ni laterite ore in two operating plants located in the Goiás State, Brazil. Our study reports the first $\mathrm{Ni}$ isotope data on feeding materials, products and waste materials involved in the different steps of a metallurgical process. The second objective of the paper is to evaluate the potential use of $\mathrm{Ni}$ isotopes to discriminate the "anthropogenic" $\mathrm{Ni}$ from the "natural" one in soils sampled in the vicinity of the plants.

\section{Materials and methods}

\subsection{Settings}

According to the USGS, Brazil hosts $11.2 \%$ of the world Ni resources, with $9.110^{6}$ tons. The Brazilian production of primary Ni was estimated to 126,000 tons in 2014 (USGS, 2015). The Ni deposits of Barro Alto and Niquelândia, located in the Midwestern region of Goiás, constitute a large $\mathrm{Ni}$ reserve. The $\mathrm{Ni}$ mineralizations are found in the surficial weathered portions of the serpentinites and are mined from open pits by two main companies, 
Anglo American (Codemin mine at Niquelândia, and Barro Alto) and Votorantim Metais Níquel S.A. (Niquelândia). In 2011, the Codemin and Barro Alto plants produced 9,500 t and 6,200 t of $\mathrm{Ni}$ as FeNi (USGS, 2011), respectively, while the Ni production in Barro Alto reached 41,000 t in 2012 (Moore, 2012). The Barro Alto plant is set to produce, on average, 36,000 t/yr of Ni as FeNi for the next 25 years (Moore, 2012).

\subsection{Metallurgical process}

The FeNi production by smelting requires a mixture of saprolitic and lateritic materials as feeding material, which must have a composition close to 1.9 wt.\% Ni, $\mathrm{Fe}<18$ wt.\%, $\mathrm{SiO}_{2} / \mathrm{MgO}=1.75, \mathrm{Ni} / \mathrm{Co}>31$ and $\mathrm{Ni} / \mathrm{Cu}>26$ (Anglo American, pers. comm.).

The smelting process of laterite ores can be divided into three main steps as schematized in Figure 1. After drying, crushing and homogenization, the feeding material is calcined in rotating kiln at $900^{\circ} \mathrm{C}$, in order to convert minerals into oxides and $\mathrm{H}_{2} \mathrm{O}$ and then to reduce the resulting oxides by addition of hydrocarbons (coal/heavy fuels/eucalyptus) and reducing gases (Crundwell et al., 2011; Anglo American, pers. com.). The fly ash (F) produced at this step contains large amount of $\mathrm{Ni}$ (up to 3.09\%, Tab. 1) and is recovered on electrostatic filters. Collected fly ash is then either stored in immersed ponds or recycled into the calcination kiln. The remaining $\mathrm{Fe}$ and $\mathrm{Ni}$ oxides of the calcine are then reduced in an electric arc furnace at $1,600^{\circ} \mathrm{C}$ leading to the production of molten $\mathrm{FeNi}$ and reduction or smelting slags (SS) containing $\mathrm{SiO}_{2}, \mathrm{MgO}, \mathrm{FeO}$ as well as metals. The smelting slags are dumped in the vicinity of the plant. The molten FeNi is then refined through a two-step process that produces two types of refining slags: black refining slags (BRS) and white refining slags (WRS) after removal of phosphorus and sulfur, respectively. Given the relatively small amount of BRS and WRS produced at this step we will not consider these two components in further discussion.

In Barro Alto, a water recovery system has been installed under the disposal sites for smelting and refining slags, while in Niquelândia the slag dumps are directly in contact with compacted soil. In Niquelândia, the fly ash produced over the last decades is stored in several immersed settling ponds. 


\subsection{Sampling and sample preparation}

All the feeds and by-products of $\mathrm{Ni}$ smelting operation have been sampled: feeding material (Ore, $n=7$ ), collected either at Niquelândia or Barro Alto plants in the 2008-2014 time-period, fly ash (F, n=10), sampled either in settling ponds (wet and dry, F1-9), or directly from the electrostatic filter (F10), smelting slags $(\mathrm{SS}, \mathrm{n}=8$ ) produced during the reduction process in the electric arc furnace, white and black refining slags (WRS and BRS, $n=2$ ) and FeNi (n=2). Fly ash and slags corresponding to different smelting periods and storage conditions ( $\mathrm{n}=29 ; 20$-year-old, re-vegetated and recent) have been collected between 2008 and 2014.

In addition, two water samples in contact with fly ash have been collected in the settling ponds at Niquelândia, as well as three water samples collected in surface at Barro Alto. The water samples have been filtered through $0.20 \mu \mathrm{m}$ membrane filters in the field.

A set of 24 topsoils developed on UM rocks and non-UM rocks has been sampled in the vicinity of the plants of Barro Alto and Niquelândia in 2013 and 2014.

The samples were homogenized and finely ground before acid digestion. All of the reagents used in the digestion procedure were of analytical grade and bi-distilled. Approximately $100 \mathrm{mg}$ of the samples were transferred to Teflon vessels, digested with $5 \mathrm{~mL}$ of concentrated $\mathrm{HF}$ and $1.5 \mathrm{~mL}$ of $\mathrm{HClO}_{4}$ at $180^{\circ} \mathrm{C}$ and then evaporated to dryness. They were subsequently digested in a mixture of concentrated $\mathrm{HNO}_{3}-\mathrm{HCl}(3.75 \mathrm{~mL}$ of $\mathrm{HCl}$ and $1.25 \mathrm{~mL}$ of $\mathrm{HNO}_{3}$ ) at $150^{\circ} \mathrm{C}$ and evaporated to dryness. The samples were then taken up with $6 \mathrm{M} \mathrm{HCl}$ for chromatography separation of $\mathrm{Ni}$. For concentration measurements, aliquots of the samples were evaporated to dryness and taken up with $0.5 \mathrm{M} \mathrm{HNO}_{3}$.

\subsection{Nickel chemical purification}

The Ni chemical purification of samples is based on a two-step chromatography separation. A first set of ion-exchange chromatography columns is filled with $2 \mathrm{~mL}$ (wet volume) of anionic resin AG1-X8 in $6 \mathrm{M} \mathrm{HCl}$ (BioRad 100-200 mesh). This resin retains Fe, $\mathrm{Zn}$ and a high amount of $\mathrm{Co}$ and $\mathrm{Cu}$ (Moynier et al., 2007) while Ni remains in solution. Before the second chromatography column, a Ni double spike is added to the samples with a 
spike/natural ratio of 1 (Gueguen et al., 2013). The second set of ion-exchange chromatography columns use a specific Ni-resin $(0.5 \mathrm{~mL}$, wet volume $)$ composed of polymethacrylate containing a dimethylglyoxime (DMG) molecule that retains $\mathrm{Ni}$ onto the resin as an insoluble Ni-DMG complex at $\mathrm{pH}$ 8-9. The eluted $\mathrm{Ni}$ solution is evaporated and taken up in $\mathrm{HNO}_{3} 2 \%$. The full procedure of Ni chemical separation is described in Ratie et al. (2015).

\subsection{Analytical methods}

Measurements of cations concentrations were performed by AAS (Varian, AA240FS, Fast Sequential Atomic Absorption Spectrometer, GEOPS-Université Paris Sud). The accuracy of the AAS measurements was controlled using standard solutions (EPL3, EPH3 and ESH2, SCP Science) and was always better than $8 \%$ relative standard deviation (RSD) with respect to certified values.

Nickel isotope ratios were measured with a Neptune (Thermo-Electron) MC-ICP-MS at the Pôle Spectrométrie Océan (PSO), of IFREMER (Centre de Brest, France). The samples and standards were introduced via an ApexQ (50-75 V per $\mu \mathrm{g} / \mathrm{mL}$ ) in $0.28 \mathrm{M} \mathrm{HNO}_{3}$. A single "run" consisted of one block of 40 measurements. During the measurement, the Ni concentration (spike + natural) in the sample is $200 \mu \mathrm{g} / \mathrm{L}\left({ }^{61} \mathrm{Ni} /{ }^{62} \mathrm{Ni}=1.1004\right.$ with a total $\mathrm{Ni}$ concentration of $100 \mathrm{mg} / \mathrm{L}$; Gueguen et al.,2013). The double-spike calculation procedure was based upon the method described by Siebert et al. (2001) for Mo isotope determination. This method consists of determining the corrected isotopic ratio and instrumental mass bias through iterative calculations (Albarède \& Beard, 2004; Quitté \& Oberli, 2006; Cameron et al., 2009). In addition, each sample analysis was bracketed with the measurements of the spiked Ni standard NIST SRM 986 solutions at the same concentration and same spike/standard ratio as the sample. The ratios of $\delta^{60} \mathrm{Ni}$ and $\delta^{62} \mathrm{Ni}$ were expressed in per mil and normalized to the average value of the bracketing standard SRM-986 (Eq. 1) (Gramlich et al., 1989). 


$$
\left.\delta^{60} N i=\left(\frac{\left(\frac{\delta^{60} N i}{\delta^{58} N i}\right)_{s p l e}}{\left(\frac{\delta^{60} N i}{\delta^{58} N i}\right)_{S R M-986}}-1\right) \times 1000 ; \delta^{62} N i=\left(\frac{\left(\frac{\delta^{62} N i}{\delta^{58} N i}\right)_{s p l e}}{\left(\frac{\delta^{6} N i}{\delta^{58} N i}\right)_{S R M-986}}-1\right) \times 1000 \text { (Eq. } 1\right)
$$

The long-term analytical reproducibility of the Ni standard NIST SRM 986 was $\pm 0.05 \%$ o (2SD, n=320). Full procedural duplicates $(n=4)$ show a $\delta^{60} \mathrm{Ni}$ reproducibility better than 0.03 $\% \circ$ on average. Every sample was measured three to four times, but we only report, in tables and figures, the average value with the 2 SD calculated from replicate measurements. Note that a 2 SD of $0.05 \%$ (external reproducibility) was reported when the calculated 2 SD was below $0.05 \%$.

To check for mass dependent fractionation and absence of interferences, $\delta^{62} \mathrm{Ni}$ was plotted against $\delta^{60} \mathrm{Ni}$. The slope of the regression line between $\delta^{60} \mathrm{Ni}$ and $\delta^{62} \mathrm{Ni}(0.5134)$ is, within uncertainty, identical to the theoretical slope (0.5164) expected for mass-dependent fractionation (Young et al., 2002; see Fig. 2).

\section{Results}

\subsection{Bulk compositions}

\subsubsection{Metallurgical samples}

The chemical composition of metallurgical samples from the two smelting plants located at Niquelândia and Barro Alto are summarized in Table 1. Each sample type has similar major and trace element contents at both locations. The feeding materials exhibit high $\mathrm{Fe}$ and $\mathrm{Mg}$ contents, $118-178 \mathrm{~g} / \mathrm{kg}$ and $81.4-110 \mathrm{~g} / \mathrm{kg}$, respectively, and $\mathrm{Ni}$ concentration ranging from 16.9 to $23.2 \mathrm{~g} / \mathrm{kg}$. The fly ash composition is dominated by Fe (156 - $365 \mathrm{~g} / \mathrm{kg})$, while $\mathrm{Mg}$ and $\mathrm{Ni}$ contents range from 17.3 to $110.0 \mathrm{~g} / \mathrm{kg}$ and from 7.8 to $27.6 \mathrm{~g} / \mathrm{kg}$, respectively. Smelting slags are relatively rich in $\mathrm{Mg}(153-188 \mathrm{~g} / \mathrm{kg})$, except for sample SS1 (55.1 g/kg). Smelting slags have Fe content ranging from 68.8 to $142.7 \mathrm{~g} / \mathrm{kg}$ and relatively low Ni concentration ( $\leq$ $2 \mathrm{~g} / \mathrm{kg}$ ). The refined slags (WRS and BRS) are enriched in Ca $(69.5-149 \mathrm{~g} / \mathrm{kg}$ ) compared to other samples $(0.3$ to $5.1 \mathrm{~g} / \mathrm{kg})$. Ferronickel, the final product of the smelting process, is mainly composed of Fe (66-69 wt. \%) and $\mathrm{Ni}$ (31-34 wt. \%). 
According to Moore (2012), the Anglo American plant processes 2.4 Mt/yr of Ni ores to produce $41,000 \mathrm{t} / \mathrm{yr}$ of $\mathrm{Ni}$ as $\mathrm{FeNi}$. The $\mathrm{Ni}$ amount introduced in the process, calculated using a Ni content of $1.96 \pm 0.23 \%$ (Tab. 1 ), is to $47,000 \pm 5,400 \mathrm{t} / \mathrm{yr}$. This gives a Ni production yield close to $88 \pm 10 \%$. The difference between incoming $\mathrm{Ni}$ and FeNi production would correspond to the Ni remaining in the different waste materials.

The two water samples collected in settling ponds, i.e., in contact with fly ash material, are rich in $\mathrm{Ca}$ and $\mathrm{Mg}$ and have a Ni concentration of $60-80 \mu \mathrm{g} / \mathrm{L}$ ( Tab. 3), which is within the range of the natural waters sampled in the Barro Alto massif $(\mathrm{Ni}=40-150 \mu \mathrm{g} / \mathrm{L})$.

\subsubsection{Soil samples}

Soils developed on UM rocks (Niquelândia and Barro Alto) are characterized by high Ni content (9.2 - $14.2 \mathrm{~g} / \mathrm{kg}$ ), and high $\mathrm{Mg} / \mathrm{Al}$ ratio ranging from 0.44 to 1.12 (Tab. 3). Four soils collected in Barro Alto present lower Ni content (3.3 - $7.6 \mathrm{~g} / \mathrm{kg}$ ) and low $\mathrm{Mg} / \mathrm{Al}$ (0.04 - 0.20), whereas aluminum content is relatively low in all UM soil samples $(24.6-48.7 \mathrm{~g} / \mathrm{kg})$.

In the opposite, the four topsoils sampled in non-UM zone in Niquelândia are rich in Al (88.1$109 \mathrm{~g} / \mathrm{kg}$ ) but poor in $\mathrm{Mg}, \mathrm{Ni}, \mathrm{Fe}(0.7-7.2 \mathrm{~g} / \mathrm{kg}, 0.3-1.9 \mathrm{~g} / \mathrm{kg}, 123-200 \mathrm{~g} / \mathrm{kg}$, respectively), with a very low $\mathrm{Mg} / \mathrm{Al}$ ratio (0.01 to 0.09$)$.

\subsection{Nickel isotopes}

\subsubsection{Metallurgical samples}

The solid samples collected at each step of the metallurgical process (ore, F, SS, WRS, BRS, $\mathrm{FeNi}$ ) have $\delta^{60} \mathrm{Ni}$ and $\delta^{62} \mathrm{Ni}$ values ranging from $0.01 \pm 0.05 \%$ to $0.27 \pm 0.05 \%$ and from $0.02 \pm 0.10 \%$ to $0.52 \pm 0.14 \%$, respectively (Tab. 1 , Fig. 3). The range in $\delta^{60} \mathrm{Ni}$ values exceeds five times the method external reproducibility $(0.05 \%)$.

Feeding materials, which consist in a mixture of saprolitic and lateritic ores, exhibit a large range of $\delta^{60} \mathrm{Ni}$ values $(0.02 \pm 0.10 \%$ o to $0.20 \pm 0.05 \%$, median value $=0.04 \%$ o, $\mathrm{n}=7)$ that is identical to that of fly ash samples $(0.01 \pm 0.05 \%$ o to $0.20 \pm 0.05 \%$, median value $=0.04 \%$, 
$\mathrm{n}=10)$. The FeNi produced has a $\delta^{60} \mathrm{Ni}$ composition $(0.04-0.07 \%$, $\mathrm{n}=2)$ that is similar to the median value calculated for the feeding materials. However, smelting slags have the heaviest $\delta^{60} \mathrm{Ni}$ composition of all the smelter samples, with $\delta^{60} \mathrm{Ni}$ ranging from $0.11 \pm 0.05 \%$ to 0.27 $\pm 0.05 \%$ \% $(\mathrm{n}=8)$ and a median value significantly higher $(0.18 \%$ ) than the other sample types. The refining slags, BRS and WRS have respectively a $\delta^{60} \mathrm{Ni}$ of $0.03 \pm 0.06 \%$ and $0.14 \pm 0.06$ $\%$.

Finally, the two water samples collected on the Barro Alto ultramafic area display $\delta^{60} \mathrm{Ni}$ values of $0.50 \pm 0.02 \%$ and $0.70 \pm 0.02 \%$, lighter than the two water samples collected on the fly ash dumps $\left(\delta^{60} \mathrm{Ni}=1.63 \pm 0.13 \%\right.$ o to $1.81 \pm 0.10 \%$, Tab. 2$)$.

\subsubsection{Soil samples}

The $\delta^{60} \mathrm{Ni}$ of soils ranges from $-0.26 \pm 0.09 \%$ to $0.11 \pm 0.10 \%$ ( $\mathrm{n}=24 ;$ Tab. 3$)$. Soils developed on UM rocks in Barro Alto and Niquelândia show $\delta^{60} \mathrm{Ni}$ values ranging from -0.26 $\pm 0.09 \%$ to $0.11 \pm 0.10 \%$ o $(n=15)$ and from $-0.09 \pm 0.05 \%$ to $-0.04 \pm 0.05 \% \circ(n=5)$, respectively (Fig. 3). The non-UM topsoils (NQ_S5 to 8), collected at various distance from the Niquelândia metallurgical plant (from 0.1 to $20 \mathrm{~km}$ away), exhibits $\delta^{60} \mathrm{Ni}$ values ranging from $-0.19 \pm 0.13 \%$ to $0.10 \pm 0.05 \%$ o $(n=4)$. The $\delta^{60} \mathrm{Ni}$ values of non-UM topsoils show a general increase as the collection site gets closer to the metallurgical plant.

\section{Discussion}

\subsection{Fractionation of Ni isotopes during smelting and refining}

According to Moore (2012), the Barro Alto plant is designed to produce FeNi by processing $2.4 \mathrm{Mt} / \mathrm{y}$ of dry ore, at a $\mathrm{Ni}$ concentration close to $1.6 \mathrm{wt} \%$. Nickel-containing material feeding the process after drying, crushing and homogenizing, exhibits a large range of $\delta^{60} \mathrm{Ni}$ values ( 0.02 to $0.20 \%$, with an average of $0.08 \pm 0.08 \%$ o, $n=7)$. This feeding material results of the mixture of saprolitic and lateritic materials but also of the fly ash. Its bulk composition is therefore variable in term of Ni-bearing constituents, like clay minerals and Fe-oxides (Ratié et al., 2015). Such Ni-bearing minerals are present in both saprolitic and lateritic units of the exploited weathering profiles, whose $\mathrm{Ni}$ isotopic compositions vary from -0.61 to + 
$0.32 \%$ and 0.00 to $+0.13 \%$, respectively (Ratié et al., 2015). The mixing in different proportions of those types of materials to match the optimal conditions of ore processing can explain the variable $\delta^{60} \mathrm{Ni}$ values of the feeding material used in the process (Fig. 4).

In the electric arc furnace, nickel oxide is reduced to produce $\mathrm{Ni}$ metal in FeNi alloy, the final Ni product. Ferronickel has an intermediate Ni isotopic signature $\left(\delta^{60} \mathrm{Ni}=0.04-0.07 \%\right.$ ) that falls within the range of the Ni-containing feeding material. This absence of fractionation is consistent with the process efficiency, estimated at $88 \pm 10 \%$.

The unrecovered $\mathrm{Ni}$ is lost in the fly ash, that can contain up to $3 \mathrm{wt} \% \mathrm{Ni}$, and in the smelting and refining slags $([\mathrm{Ni}]=1-6 \mathrm{~g} / \mathrm{kg})$. However, fly ash is reprocessed since the construction of the new Barro Alto plant and one can consider that only $\mathrm{Ni}$ contained in the slags is definitively lost from the process. Fly ash $\delta^{60} \mathrm{Ni}$ values $\left(\delta^{60} \mathrm{Ni}=0.01-0.20 \%\right.$, with an average of $0.07 \pm 0.07 \%$ o, $\mathrm{n}=10$ ) are similar to that of the feeding material. Assuming that fly ash are the main contributors to $\mathrm{Ni}$ atmospheric emissions from the smelter, the disseminated $\mathrm{Ni}$ cannot be isotopically distinguished from the feeding material. These results show that the calcination step is not inducing $\mathrm{Ni}$ isotope fractionation.

This trend also observed for the $\mathrm{Cu}$ isotopes in emission of a metal aerosol plume in the atmosphere around one of the major $\mathrm{Pb}-\mathrm{Zn}$ refinery (Mattielli et al., 2006). In contrast, studies about $\mathrm{Zn}$ and $\mathrm{Cd}$ fractionation during smelting and refining, have shown an enrichment in light isotopes in the fly ash (Mattielli et al., 2009, Cloquet et al., 2006; Sonke et al., 2008; Bigalke et al., 2010), significantly different from isotopic value of the feeding material. While $\mathrm{Zn}$ and $\mathrm{Cd}$ present low boiling points $\left(907^{\circ} \mathrm{C}\right.$ and $767^{\circ} \mathrm{C}$, respectively), the $\mathrm{Cu}$ and $\mathrm{Ni}$ ones are very high $\left(2,562{ }^{\circ} \mathrm{C}\right.$ and $2,913^{\circ} \mathrm{C}$, respectively). Whereas evaporation process has been shown by Wombacher et al. (2004) to induce isotopic fractionation, in the case of $\mathrm{Cd}$, the temperature of the $\mathrm{Ni}$ ore calcination step $\left(900^{\circ} \mathrm{C}\right)$ is not high enough to induce $\mathrm{Ni}$ evaporation and isotopic fractionation at this step.

The fraction of $\mathrm{Ni}$ not recovered as ferronickel ends up in the smelting and refining slags, either in the glassy or mineral matrix, or as metallic droplets (Solar et al., 2009). The smelting slags are isotopically heavier $\left(\delta^{60} \mathrm{Ni}=0.11\right.$ to $0.27 \%$, with an average of $0.18 \pm 0.05 \%$ o, $\left.\mathrm{n}=8\right)$ than FeNi (0.04-0.07\%o), highlighting that Ni fractionation occurs during the reduction of $\mathrm{Ni}^{\mathrm{II}} \mathrm{O}$. Similar heavy isotopic enrichment has been observed in smelting and refining $\mathrm{Zn}$ smelting slags (Sonke et al., 2008; Shiel et al., 2010; Bigalke et al., 2010), and Pb-Zn smelting slags, for Cd isotopes (Cloquet et al., 2006; Gao et al., 2008). Assuming that the 
reduction slags represent the last fraction of molted $\mathrm{Ni}$ during the reduction process, the corresponding fractionation factor $\left(\alpha_{\text {slag-feeding material }}\right)$ can be calculated close to 1.0001. In spite of being very low comparatively to the fractionation factors proposed by Sonke et al. 2008 (1.0002-1.0004) or Sivry et al. 2008 (1.00013-1.00062) in the case of Zn, this value highlights the significant $\mathrm{Ni}$ isotopic fractionation induced by the metallurgical process in the reduction slags.

\subsection{Ultramafic soil $v s$ non-UM soils}

The chemical composition of the soil samples collected on the UM complexes of Barro Alto and Niquelândia is consistent with previous published data (Reeves et al., 2007; Garnier et al., 2009 ; Van der Ent et al., 2015). The four topsoils sampled on the non-UM complex "Anápolis-Itauçu" can be clearly distinguished from the topsoils developed on UM rocks, due to their low Ni content (from 0.3 to $1.9 \mathrm{~g} / \mathrm{kg}$ ) and their low $\mathrm{Mg} / \mathrm{Al}$ ratio (Fig. 5).

The $\delta^{60} \mathrm{Ni}$ values of the soils developed on UM rocks collected in Barro Alto and Niquelândia range from $-0.26 \pm 0.09 \%$ to $0.11 \pm 0.10 \%$, and are consistent with the few $\delta^{60} \mathrm{Ni}$ values reported so far for soils developed on UM rocks (Estrade et al., 2015; Ratié et al., 2015). $\delta^{60} \mathrm{Ni}$ values of the non-UM topsoils exhibit also a large variation in $\mathrm{Ni}$ isotopic composition $\left(\delta^{60} \mathrm{Ni}\right.$ $=-0.17$ to $0.10 \%$ o, $\mathrm{n}=4$ ) but are not significantly different from topsoils developed on UM rocks. However, in the samples NQ_S8, the high value of Ni and Mg content combined to the heavy $\delta^{60} \mathrm{Ni}$ value can be reasonably assumed to be linked to anthropogenic contamination

\subsection{Implications for tracing Ni contamination}

Values of $\delta^{60} \mathrm{Ni}$ published so far for terrestrial samples are compiled together with our data in the figure 6 . The published $\delta^{60} \mathrm{Ni}$ values for "natural" terrestrial samples range from $1.03 \%$ to $2.50 \%$ (see citations in figure caption). The $\delta^{60} \mathrm{Ni}$ values reported in this study for anthropogenic samples $(0.01$ to $0.27 \%$ ), fall within the range of terrestrial sample signatures. The potential anthropogenic impact of the smelter can be induced by both particulate and dissolved metals released from smelting sub-product. Isotopes have already proved that they 
can be used as tracer of such contaminations (e.g. Bigalke et al., 2010; Sivry et al., 2008; Sonke et al., 2008; Cloquet et al., 2006; Wen et al., 2015; Chrastny et al., 2015). In the case of the Niquelândia and Barro Alto smelters, and considering the errors bars (2SD), FeNi and fly ash $\delta^{60} \mathrm{Ni}$ values cannot be considered significantly different. The isotopic compositions of contamination source issued from pyrometallurgical process are not significantly different from isotopic composition of terrestrial samples observed in the soils and in the UM complex. This feature emphasizes that the use of $\mathrm{Ni}$ isotopes for tracing environmental contamination from smelters still remains challenging. However, the isotopic composition of dissolved $\mathrm{Ni}$ of the settling pond water, i.e. in contact with fly ash for a long period, is heavier than the Ni isotopic composition of fly ash. Moreover, it is also heavier than the dissolved Ni of the water collected in the UM massif. This would imply that the release of $\mathrm{Ni}$ from anthropogenic material, such as fly ash, can be distinguished from naturally dissolved $\mathrm{Ni}$. Therefore, the $\mathrm{Ni}$ isotopic signature in the dissolved phase could be promising to track an eventual contamination of surface and groundwater. Further experiments are needed to evaluate the impact of the waste storage on their isotopic signature. In that way, preliminary leaching experiments have been performed on fly ash and slag at acid $\mathrm{pH}$ (supplementary data 1) in order to evaluate the impact of $\mathrm{H}^{+}$-promoted weathering on the $\delta^{60} \mathrm{Ni}$ signature. The first results seem to show that the preferential dissolution of some of the Ni-bearing phases such as Ni-bearing serpentine-like phases, Ni-glass and olivine leads to the release of heavy $\mathrm{Ni}$.

\section{Conclusion}

The present study on two metallurgical plants has shown that part of smelting and refining activities induce a fractionation of $\mathrm{Ni}$ isotopes with a range of $\delta^{60} \mathrm{Ni}$ values from $0.01 \pm 0.05$ $\%$ (fly ash) to $0.27 \pm 0.05 \%$ (smelting slags), consistent with the mass dependent law. Fly ash $\delta^{60} \mathrm{Ni}$ values are similar to that of feeding material, showing that the calcination step is not inducing a $\mathrm{Ni}$ fractionation. Ferronickel, i.e. the final Ni product, has an intermediate $\mathrm{Ni}$ isotopic signature that falls within the range of the feeding material, which is consistent with the very high Ni recovery yield of the entire process.

The enrichment in heavier isotopes in smelting slags, probably due to redox process in the electric furnace, highlights the potential impact of smelting activity in the surrounding area. 
Moreover, dissolved $\mathrm{Ni}$ from the settling ponds, where fly ash is stored, appears to be enriched in heavy isotopes compared to pristine water. These results highlight the potential value of $\mathrm{Ni}$ isotopes to distinguish anthropogenic $\mathrm{Ni}$ (heavier $\delta^{60} \mathrm{Ni}$ signatures) from natural one (lighter $\delta^{60} \mathrm{Ni}$ values). However, the whole range of $\delta^{60} \mathrm{Ni}$ values published so far for terrestrial samples is larger than the range of $\delta^{60} \mathrm{Ni}$ values of metallurgical by-product. This feature emphasizes that the use of $\mathrm{Ni}$ isotopes for tracing environmental contamination from smelters still remains challenging.

\section{Acknowledgements}

This work was financially supported by the French Ministry of National Education and Research (G. Ratié PhD grant), National French Program EC2CO from INSU, CNRS, and a Marie Curie International Research Staff Exchange Scheme Fellowship within the 7th European Community Framework Programme (NIDYFICS, $\mathrm{n}^{\circ} 318123$ ). This work also benefited from the Ciencia sem Fronteiras program (C. Quantin). The authors wish to thank Anglo American for access to their field facilities, and the staff for help during sampling, as well as O. Rouxel (IFREMER, France) for the Ni double spike preparation.

\section{References}

Albarede, F., \& Beard, B. (2004). Analytical methods for non-traditional isotopes. In C. M. Johnson, B. L. Beard, \& F. Albarede (Eds.), Geochemistry of Non-Traditional Stable Isotopes (Vol. 55, pp. 113-152).

Bigalke, M., Weyer, S., Kobza, J., \& Wilcke, W. (2010). Stable $\mathrm{Cu}$ and $\mathrm{Zn}$ isotope ratios as tracers of sources and transport of $\mathrm{Cu}$ and $\mathrm{Zn}$ in contaminated soil. Geochimica Et Cosmochimica Acta, 74(23), 6801-6813. http://doi.org/10.1016/j.gca.2010.08.044

Butt, C. R. M., \& Cluzel, D. (2013). Nickel Laterite Ore Deposits: Weathered Serpentinites. Elements, 9(2), 123-128. http://doi.org/10.2113/gselements.9.2.123

Buzier, R., Tusseau-Vuillemin, M.-H., Keirsbulck, M., \& Mouchel, J.-M. (2011). Inputs of total and labile trace metals from wastewater treatment plants effluents to the Seine River. 
Physics and Chemistry of the Earth, 36(12), 500-505. http://doi.org/10.1016/j.pce.2008.09.003

Cameron, V., \& Vance, D. (2014). Heavy nickel isotope compositions in rivers and the oceans. Geochimica et Cosmochimica Acta, 128(0), 195-211. http://doi.org/10.1016/j.gca.2013.12.007

Cameron, V., Vance, D., Archer, C., \& House, C. H. (2009). A biomarker based on the stable isotopes of nickel. Proceedings of the National Academy of Sciences of the United States of America, 106(27), 10944-10948. http://doi.org/10.1073/pnas.0900726106

CEN/TS 14997, Characterization of waste - Leaching behaviour tests - Influence of pH on leaching with continuous pH-control, CEN, Brussels (2006).

Chen, J., Gaillardet, J., \& Louvat, P. (2008). Zinc isotopes in the Seine River waters, France: A probe of anthropogenic contamination. Environmental Science \& Technology, 42(17), 6494-6501. http://doi.org/10.1021/es800725z

Chrastný, V., Čadková, E., Vaněk, A., Teper, L., Cabala, J., \& Komárek, M. (2015). Cadmium isotope fractionation within the soil profile complicates source identification in relation to $\mathrm{Pb}-\mathrm{Zn}$ mining and smelting processes. Chemical Geology, 405(0), 1-9. http://doi.org/10.1016/j.chemgeo.2015.04.002

Cloquet, C., Carignan, J., Libourel, G., Sterckeman, T., \& Perdrix, E. (2006). Tracing source pollution in soils using cadmium and lead isotopes. Environmental Science \& Technology, 40(8), 2525-2530. http://doi.org/10.1021/es052232+

Colin, F., Noack, Y., Trescases, J. J., \& Nahon, D. (1985). The initial lateritic weathering of pyroxenites from Jacuba Niquelândia, Brazil., pp. 93-113.

Crundwell, F. K., Moats, M. S., Ramachandran, V., Robinson, T. G., \& Davenport, W. G. (2011). Chapter 1 - Overview. In F. K. C. S. M. R. G. R. G. Davenport (Ed.), Extractive Metallurgy of Nickel, Cobalt and Platinum Group Metals (pp. 1-18). Oxford: Elsevier. Retrieved from http://www.sciencedirect.com/science/article/pii/B9780080968094100012

Dalvi, A. D., Bacon, W. G., \& Osborne, R. C. (2004). Past and future of nickel laterite projects. (W. P. Imrie \& D. M. Lane, Eds.).

Dublet, G., Juillot, F., Morin, G., Fritsch, E., Fandeur, D., Ona-Nguema, G., \& Brown, G. E. (2012). Ni speciation in a New Caledonian lateritic regolith: A quantitative X-ray absorption spectroscopy investigation. Geochimica Et Cosmochimica Acta, 95, 119-133. http://doi.org/10.1016/j.gca.2012.07.030

Dublet, G., Juillot, F., Morin, G., Fritsch, E., Fandeur, D., Brown Jr, G.E. (2015). Goethite aging explains Ni depletion in upper units of ultramafic lateritic ores from New Caledonia. Geochimica Et Cosmochimica Acta, 160, 1-15. http://dx.doi.org/10.1016/j.gca.2015.03.015

Estrade, N., Cloquet, C., Echevarria, G., Sterckeman, T., Deng, T., Tang, Y., \& Morel, J.-L. (2015). Weathering and vegetation controls on nickel isotope fractionation in surface 
ultramafic environments (Albania). Earth and Planetary Science Letters, 423(0), 24-35. http://doi.org/10.1016/j.eps1.2015.04.018

Ettler, V., Mihaljevic, M., Sebek, O., \& Strnad, L. (2005). Leaching of APC residues from secondary $\mathrm{Pb}$ metallurgy using single extraction tests: the mineralogical and the geochemical approach. Journal of Hazardous Materials, 121(1-3), 149-157. http://doi.org/10.1016/j.jhazmat.2005.02.001

Fan, R., \& Gerson, A. R. (2011). Nickel geochemistry of a Philippine laterite examined by bulk and microprobe synchrotron analyses. Geochimica Et Cosmochimica Acta, 75(21), 6400-6415. http://doi.org/10.1016/j.gca.2011.08.003

Gall, L., Williams, H., Siebert, C., \& Halliday, A. (2012). Determination of mass-dependent variations in nickel isotope compositions using double spiking and MC-ICPMS. Journal of Analytical Atomic Spectrometry, 27(1), 137-145. http://doi.org/10.1039/c1ja10209e

Gall, L., Williams, H. M., Siebert, C., Halliday, A. N., Herrington, R. J., \& Hein, J. R. (2013). Nickel isotopic compositions of ferromanganese crusts and the constancy of deep ocean inputs and continental weathering effects over the Cenozoic. Earth and Planetary Science Letters, 375, 148-155. http://doi.org/10.1016/j.epsl.2013.05.019

Gao, B., Liu, Y., Sun, K., Liang, X., Peng, P., Sheng, G., \& Fu, J. (2008). Precise determination of cadmium and lead isotopic compositions in river sediments. Analytica Chimica Acta, 612(1), 114-120. http://doi.org/10.1016/j.aca.2008.02.020

Garnier, J., Quantin, C., Guimaraes, E., Garg, V. K., Martins, E. S., \& Becquer, T. (2009). Understanding the genesis of ultramafic soils and catena dynamics in Niquelandia, Brazil. Geoderma, 151(3-4), 204-214. http://doi.org/10.1016/j.geoderma.2009.04.020

Gaudin, A., Grauby, O., Noack, Y., Decarreau, A., \& Petit, S. (2004). Accurate crystal chemistry of ferric smectites from the lateritic nickel ore of Murrin Murrin (Western Australia). I. XRD and multi-scale chemical approaches. Clay Minerals, 39(3), 301-315. http://doi.org/10.1180/0009855043930136

Gleeson, S. A., Herrington, R. J., Durango, J., Velasquez, C. A., \& Koll, G. (2004). The mineralogy and geochemistry of the Cerro Matoso SA Ni laterite deposit, Montelibano, Colombia. Economic Geology, 99(6), 1197-1213. http://doi.org/10.2113/99.6.1197

Gramlich, J., Machlan, L., Barnes, I., \& Paulsen, P. (1989). Absolute isotopic abundance ratios and atomic weight of a reference sample of nickel. Journal of Research of the National Institute of Standards and Technology, 94(6), 347-356. http://doi.org/10.6028/jres.094.034

Gray, J. E., Pribil, M. J., Van Metre, P. C., Borrok, D. M., \& Thapalia, A. (2013). Identification of contamination in a lake sediment core using $\mathrm{Hg}$ and $\mathrm{Pb}$ isotopic compositions, Lake Ballinger, Washington, USA. Applied Geochemistry, 29, 1-12. http://doi.org/10.1016/j.apgeochem.2012.12.001 
Gueguen, B., Rouxel, O., Ponzevera, E., Bekker, A., \& Fouquet, Y. (2013). Nickel Isotope Variations in Terrestrial Silicate Rocks and Geological Reference Materials Measured by MC-ICP-MS. Geostandards and Geoanalytical Research, 37(3), 297-317. http://doi.org/10.1111/j.1751-908X.2013.00209.x

Hoatson, D. M., Jaireth, S., \& Jaques, A. L. (2006). Nickel sulfide deposits in Australia: Characteristics, resources, and potential. Ore Geology Reviews, 29(3-4), 177-241. http://doi.org/10.1016/j.oregeorev.2006.05.002

Manceau, A., \& Calas, G. (1985). Heterogeneous distribution of nickel in hydrous silicates from new caledonia ore-deposits. American Mineralogist, 70(5-6), 549-558.

Manceau, A., Schlegel, M. L., Musso, M., Sole, V. A., Gauthier, C., Petit, P. E., \& Trolard, F. (2000). Crystal chemistry of trace elements in natural and synthetic goethite. Geochimica Et Cosmochimica Acta, 64(21), 3643-3661. http://doi.org/10.1016/S0016-7037(00)00427-0

Mattielli, N., Petit, J. C. J., Deboudt, K., Flament, P., Perdrix, E., Taillez, A., RimetzPlanchon, J., Weis, D. (2009). Zn isotope study of atmospheric emissions and dry depositions within a $5 \mathrm{~km}$ radius of a $\mathrm{Pb}-\mathrm{Zn}$ refinery. Atmospheric Environment, 43(6), 1265-1272. http://doi.org/10.1016/j.atmosenv.2008.11.030

Mattielli, N., Rimetz, J., Petit, J., Perdrix, E., Deboudt, K., Flament, P., \& Weis, D. (2006). $\mathrm{Zn}-\mathrm{Cu}$ isotopic study and speciation of airborne metal particles within a 5-km zone of a lead/zinc smelter. Geochimica Et Cosmochimica Acta, 70(18), A401-A401. http://doi.org/10.1016/j.gca.2006.06.808

Moore, P. (2012). Anglo's new nickel. International Mining, March 2012, 20-24

Moynier, F., Blichert-Toft, J., Telouk, P., Luck, J.-M., \& Albarede, F. (2007). Comparative stable isotope geochemistry of $\mathrm{Ni}, \mathrm{Cu}, \mathrm{Zn}$, and $\mathrm{Fe}$ in chondrites and iron meteorites. $\begin{array}{lllll}\text { Geochimica Et } \quad \text { Cosmochimica } & \text { Acta, }\end{array}$ http://doi.org/10.1016/j.gca.2007.06.049

Mudd, G. M. (2010). Global trends and environmental issues in nickel mining: Sulfides versus laterites. Ore Geology Reviews, 38(1-2), 9-26. http://doi.org/10.1016/j.oregeorev.2010.05.003

Naldrett, A. J., Hoffman, E. L., Green, A. H., Chou, C.-L., Naldrett, S. R., \& Alcock, R. A. (1979). The composition of Ni-sulfide ores, with particular reference to their content of PGE and Au. Canadian Mineralogist, 17, 403-415.

Nickel institute 2013

http://www.nickelinstitute.org/NickelUseInSociety/MaterialsSelectionAndUse/Ni

ContainingMaterialsProperties/StainlessSteels.aspx

Porter, S. J., Selby, D., \& Cameron, V. (2014). Characterising the nickel isotopic composition of organic-rich marine sediments. Chemical Geology, 387(0), 12-21. http://doi.org/10.1016/j.chemgeo.2014.07.017 
Quantin, C., Becquer, T., Rouiller, J. H., \& Berthelin, J. (2002). Redistribution of metals in a New Caledonia ferralsol after microbial weathering. Soil Science Society of America Journal, 66(6), 1797-1804.

Quitte, G., \& Oberli, F. (2006). Quantitative extraction and high precision isotope measurements of nickel by MC-ICPMS. Journal of Analytical Atomic Spectrometry, 21(11), 1249-1255. http://doi.org/10.1039/b607569j

Ratié, G., Jouvin, D., Garnier, J., Rouxel, O., Miska, S., Guimarães, E., Cruz Viera, L., Sivry, Y., Zelano, I., Montargès-Pelletier, E., Thil, F., Quantin, C. (2015). Nickel isotope fractionation during tropical weathering of ultramafic rocks. Chemical Geology, 402(0), 6876. http://doi.org/10.1016/j.chemgeo.2015.02.039

Reeves, R. D., Baker, A. J. M., Becquer, T., Echevarria, G., \& Miranda, Z. J. G. (2007). The flora and biogeochemistry of the ultramafic soils of Goias state, Brazil. Plant and Soil, 293(12), 107-119. http://doi.org/10.1007/s11104-007-9192-x

Romic, M., \& Romic, D. (2003). Heavy metals distribution in agricultural topsoils in urban area. Environmental Geology, 43(7), 795-805. http://doi.org/10.1007/s00254-002-0694-9

Shiel, A. E., Weis, D., \& Orians, K. J. (2010). Evaluation of zinc, cadmium and lead isotope fractionation during smelting and refining. Science of the Total Environment, 408(11), 23572368. http://doi.org/10.1016/j.scitotenv.2010.02.016

Sivry, Y., Riotte, J., Sonke, J. E., Audry, S., Schäfer, J., Viers, J., Blanc, G., Freydier, R., Dupré, B. (2008). Zn isotopes as tracers of anthropogenic pollution from $\mathrm{Zn}$-ore smelters The Riou Mort-Lot River system. Chemical Geology, 255(3-4), 295-304. http://doi.org/10.1016/j.chemgeo.2008.06.038

Solar, M. Y., Candy, I., \& Wasmund, B. (2008). Selection of Optimum Ferronickel Grade for Smelting Nickel Laterites. CIM Bulletin, (101), 1-8.

Sonke, J. E., Sivry, Y., Viers, J., Freydier, R., Dejonghe, L., Andre, L., Aggarwal, J. K., Fontan, F., Dupre, B. (2008). Historical variations in the isotopic composition of atmospheric zinc deposition from a zinc smelter. Chemical Geology, 252(3-4), 145-157. http://doi.org/10.1016/j.chemgeo.2008.02.006

Stetson, S. J., Gray, J. E., Wanty, R. B., \& Macalady, D. L. (2009). Isotopic Variability of Mercury in Ore, Mine-Waste Calcine, and Leachates of Mine-Waste Calcine from Areas Mined for Mercury. Environmental Science \& Technology, 43(19), 7331-7336. http://doi.org/10.1021/es9006993

USGS 2011, Nickel. USGS Mineral Resources Program (available from http://minerals.usgs.gov/minerals/pubs/commodity/nickel/myb1-2011-nicke.pdf)

USGS, 2015. Nickel. USGS Mineral Resources Program (available from http://minerals.usgs.gov/minerals/pubs/commodity/nickel/mcs-2015-nicke.pdf) 
Van der Ent, A., \& Reeves, R. D. (2015). Foliar metal accumulation in plants from copperrich ultramafic outcrops: case studies from Malaysia and Brazil. Plant and Soil, 389(1-2), 401-418. http://doi.org/10.1007/s11104-015-2385-9

Ventura, G. T., Gall, L., Siebert, C., Prytulak, J., Szatmari, P., Hürlimann, M., \& Halliday, A. N. (2015). The stable isotope composition of vanadium, nickel, and molybdenum in crude oils. Applied Geochemistry, 59, 104-117. http://doi.org/10.1016/j.apgeochem.2015.04.009

Villanova-de-Benavent, C., Proenza, J. A., Galí, S., García-Casco, A., Tauler, E., Lewis, J. F., \& Longo, F. (2014). Garnierites and garnierites: Textures, mineralogy and geochemistry of garnierites in the Falcondo Ni-laterite deposit, Dominican Republic. Ore Geology Reviews, 58, 91-109.

Weiss, D. J., Rehkamper, M., Schoenberg, R., McLaughlin, M., Kirby, J., Campbell, P. G. C., Arnold, T., Chapman, J., Peel, K., Gioia, S. (2008). Application of nontraditional stableisotope systems to the study of sources and fate of metals in the environment. Environmental Science \& Technology, 42(3). http://doi.org/10.1021/es0870855

Wells, M. A., Ramanaidou, E. R., Verrall, M., \& Tessarolo, C. (2009). Mineralogy and crystal chemistry of "garnierites" in the Goro lateritic nickel deposit, New Caledonia. European Journal of Mineralogy, 21(2), 467-483. http://doi.org/10.1127/0935-1221/2009/0021-1910

Wiederhold, J. G. (2015). Metal Stable Isotope Signatures as Tracers in Environmental Geochemistry. Environmental Science \& Technology, 49(5), 2606-2624. http://doi.org/10.1021/es504683e

Wombacher, F., Rehkamper, M., \& Mezger, K. (2004). Determination of the massdependence of cadmium isotope fractionation during evaporation. Geochimica Et Cosmochimica Acta, 68(10), 2349-2357. http://doi.org/10.1016/j.gca.2003.12.013

Young, E. D., Galy, A., \& Nagahara, H. (2002). Kinetic and equilibrium mass-dependent isotope fractionation laws in nature and their geochemical and cosmochemical significance. Geochimica et Cosmochimica Acta, 66(6), 1095-1104. 
Table 1: Total contents of elements and $\mathrm{Ni}$ isotopic composition $\left(\delta^{60} \mathrm{Ni}, \delta^{62} \mathrm{Ni}\right)$ of mixed Ores (Ore), Fly ash (F), Smelting Slags (SS, a old, ${ }^{b}$ recent), White Refining Slags (WRS), Black Refining Slags (BRS), FeNi.

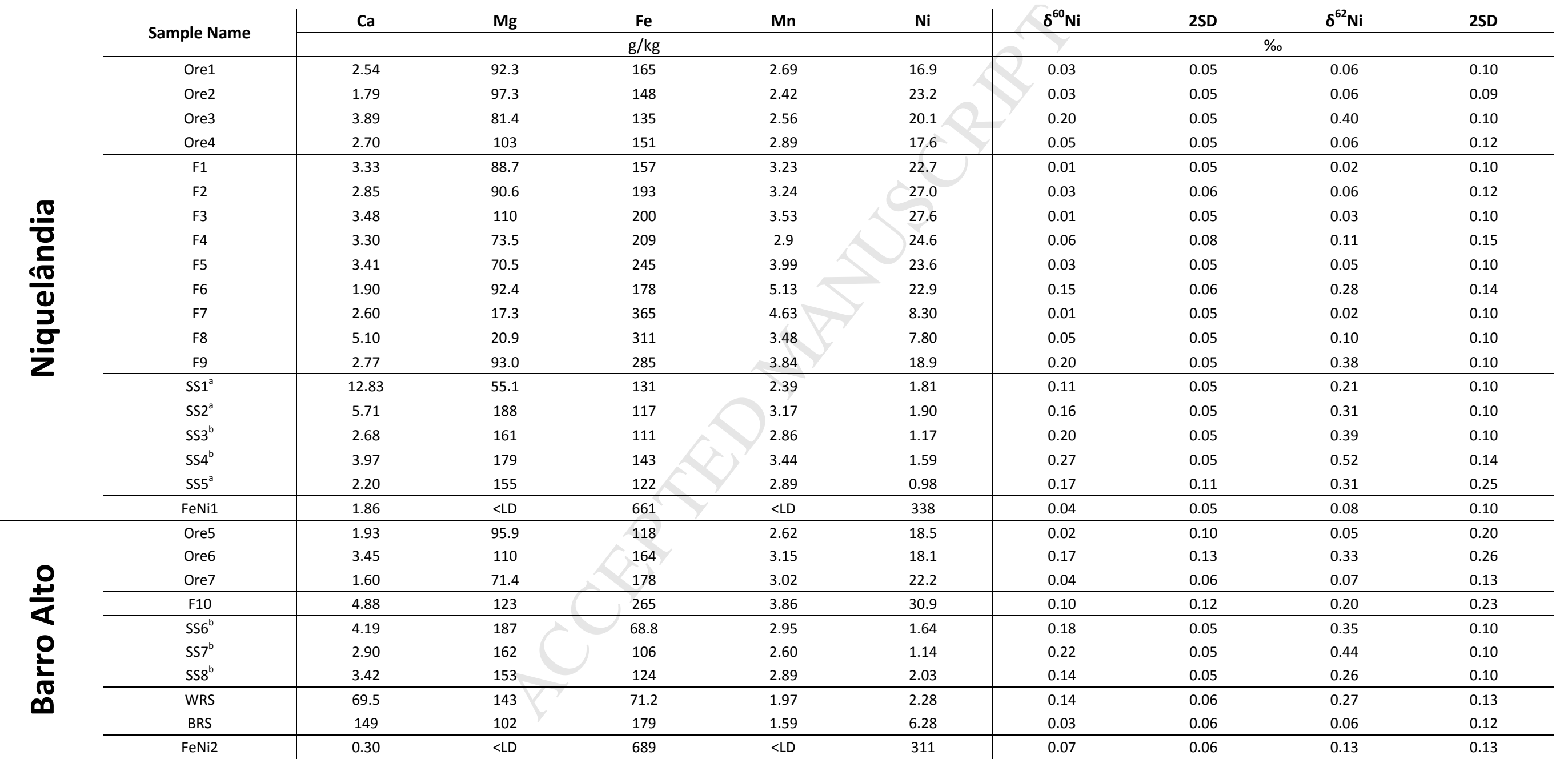


Table 2: Elemental concentration $(\mathrm{mg} / \mathrm{L})$ after filtration $(<0.45 \mu \mathrm{m})$ and $\mathrm{Ni}$ isotopic composition $\left(\delta^{60} \mathrm{Ni}, \delta^{62} \mathrm{Ni}\right)$ of the water samples collected in surface of the Barro Alto massif (BA_W) and in settling ponds at Niquelândia (F_W).

\begin{tabular}{|c|c|c|c|c|c|c|c|c|c|}
\hline & $\mathrm{Ca}$ & $\mathrm{Mg}$ & $\mathrm{Na}$ & K & $\mathrm{Ni}$ & $\delta^{60} \mathrm{Ni}$ & $2 S D$ & $\delta^{62} \mathrm{Ni}$ & $2 S D$ \\
\hline & \multicolumn{5}{|c|}{$\mathrm{mg} / \mathrm{L}$} & \multicolumn{4}{|c|}{$\%$} \\
\hline BA_W_1 & 1.03 & 21.64 & $<\mathrm{LD}$ & 0.35 & 0.15 & 0.50 & 0.02 & 0.98 & 0.03 \\
\hline BA_W_2 & 1.83 & 17.04 & $<\mathrm{LD}$ & 0.25 & 0.07 & 0.60 & 0.11 & 1.18 & 0.21 \\
\hline BA_W_3 & 1.90 & 11.25 & $<L D$ & 0.21 & 0.04 & 0.70 & 0.02 & 1.37 & 0.04 \\
\hline F_W & 18.52 & 87.24 & 0.12 & 3.93 & 0.06 & 1.63 & 0.13 & 3.21 & 0.25 \\
\hline$F^{-} 2$ & 17.59 & 78.52 & 0.13 & 2.28 & 0.08 & 1.81 & 0.10 & 3.56 & 0.20 \\
\hline
\end{tabular}


Table 3: Chemical and isotopic composition $\left(\delta^{60} \mathrm{Ni}\right.$ and $\delta^{62} \mathrm{Ni}$ in \%o) of soils collected in Barro Alto and Niquelândia; sample color according to the Munsell chart and localization (UM BA: in the UM Barro Alto complex, UM Niq: in the UM Niquelândia complex, non UM Niq: outside the UM Niquelândia complex)

\begin{tabular}{|c|c|c|c|c|c|c|c|c|c|c|c|c|c|}
\hline \multirow{2}{*}{ Sample name } & \multirow{2}{*}{ Sample color } & \multirow{2}{*}{ Localisation } & \multirow[t]{2}{*}{$\mathrm{K}$} & \multirow[t]{2}{*}{$\mathrm{Ca}$} & \multirow[t]{2}{*}{$\mathrm{Mg}$} & \multirow{2}{*}{$\begin{array}{l}\text { Al } \\
\mathrm{g} / \mathrm{kg}\end{array}$} & \multirow{2}{*}{\multicolumn{2}{|c|}{$\mathrm{Mn}$}} & \multirow[t]{2}{*}{$\mathrm{Ni}$} & \multirow{2}{*}{\multicolumn{4}{|c|}{$0 \mathrm{NI}$}} \\
\hline & & & & & & & & & & & & & \\
\hline BA_S1 & $2.5 Y R 2.5 / 3$ & UM BA & 0.12 & 4.20 & 24.92 & 24.64 & 290.82 & 5.16 & 12.80 & -0.09 & 0.05 & -0.18 & 0.03 \\
\hline BA_S2 & 2.5YR $2.5 / 3$ & UM BA & 0.13 & 3.65 & 16.88 & 26.22 & 298.48 & 5.07 & 10.80 & -0.19 & 0.05 & -0.38 & 0.02 \\
\hline BA_S3 & 2.5 YR $2.5 / 2$ & UM BA & 0.15 & 6.37 & 19.03 & 42.36 & 318.28 & 5.16 & 9.77 & -0.15 & 0.05 & -0.29 & 0.10 \\
\hline BA_S4 $0-4 \mathrm{~cm}$ & $2.5 Y R 2.5 / 3$ & UM BA & 0.20 & 4.53 & 20.03 & 43.97 & 307.36 & 5.00 & 9.85 & -0.16 & 0.05 & -0.32 & 0.01 \\
\hline BA_S4 10-15cm & $2.5 Y R 2.5 / 3$ & UM BA & 0.16 & 5.04 & 19.53 & 48.70 & 343.75 & 5.42 & 10.87 & -0.15 & 0.05 & -0.30 & 0.07 \\
\hline BA_S4 $50-55 \mathrm{~cm}$ & 5YR $2.5 / 2$ & UM BA & 0.12 & 8.85 & 35.51 & 44.33 & 304.54 & 4.67 & 11.71 & -0.16 & 0.05 & -0.31 & 0.04 \\
\hline BA_S5 & $2.5 Y R 3 / 2$ & UM BA & 0.17 & 0.50 & 6.37 & 35.31 & 336.24 & 5.19 & 7.48 & -0.10 & 0.08 & -0.19 & 0.17 \\
\hline BA_S6 & $2.5 Y R 3 / 3$ & UM BA & 0.10 & 0.29 & 4.31 & 34.62 & 357.32 & 6.26 & 7.59 & -0.14 & 0.05 & -0.27 & 0.03 \\
\hline BA_S7 & 2.5YR $2.5 / 3$ & UM BA & 0.13 & 0.06 & 1.47 & 35.21 & 390.30 & 5.23 & 4.30 & 0.10 & 0.05 & 0.19 & 0.06 \\
\hline BA_S8 & $10 R 3 / 2$ & UM BA & 0.17 & 0.12 & 1.19 & 32.94 & 278.32 & 3.75 & 3.25 & 0.11 & 0.10 & 0.21 & 0.11 \\
\hline BA_S9 & $2.5 Y R 2.5 / 3$ & UM BA & 0.15 & 5.80 & 16.63 & 37.51 & 347.16 & 5.05 & 10.43 & -0.20 & 0.13 & -0.39 & 0.25 \\
\hline BA_S10 & $2.5 Y R 3 / 4$ & UM BA & 0.20 & 2.76 & 14.55 & 36.78 & 314.51 & 4.30 & 9.24 & -0.09 & 0.08 & -0.18 & 0.16 \\
\hline BA_S11 & $5 Y R 2.5 / 3$ & UM BA & 0.18 & 8.23 & 20.42 & 33.46 & 356.00 & 5.75 & 10.70 & -0.26 & 0.09 & -0.52 & 0.17 \\
\hline BA_S12 & $2.5 Y R 2.5 / 3$ & UM BA & 0.14 & 4.60 & 22.94 & 36.27 & 509.60 & 7.01 & 14.16 & -0.17 & 0.05 & -0.34 & 0.10 \\
\hline BA_S13 & $2.5 Y R 3 / 4$ & UM BA & 0.16 & 8.42 & 24.69 & 30.17 & 410.59 & 7.12 & 13.72 & -0.30 & 0.06 & -0.58 & 0.12 \\
\hline NQ_S1 3-10cm & $10 R 3 / 3$ & UM Niq & 0.11 & 0.71 & 22.75 & 23.87 & 364.84 & 6.82 & 9.21 & $\begin{array}{l}-0.07 \\
\end{array}$ & 0.05 & -0.14 & 0.09 \\
\hline NQ_S1 $35-45 \mathrm{~cm}$ & 10R $2.5 / 2$ & UM Niq & 0.07 & 0.90 & 20.45 & 21.54 & 339.82 & 6.37 & 8.40 & -0.04 & 0.05 & -0.07 & 0.02 \\
\hline NQ_S2 & $10 \mathrm{R} 3 / 4$ & UM Niq & 0.10 & 0.36 & 14.94 & 22.27 & 459.66 & 7.91 & 10.07 & -0.06 & 0.05 & -0.12 & 0.06 \\
\hline NQ_S3 & $10 R 3 / 3$ & UM Niq & 0.08 & 0.42 & 16.12 & 19.20 & 457.40 & 7.74 & 9.39 & -0.09 & 0.05 & -0.17 & 0.09 \\
\hline NQ_S4 & 10R $2.5 / 2$ & UM Niq & 0.12 & 0.32 & 16.47 & 21.90 & 517.38 & 9.53 & 12.24 & -0.05 & 0.14 & -0.10 & 0.28 \\
\hline NQ_S8 & $5 Y R 3 / 3$ & non UM Niq ( $0.1 \mathrm{~km}$ of plant) & 1.17 & 0.56 & 7.22 & 84.91 & 122.70 & 1.38 & 1.92 & 0.10 & 0.05 & 0.20 & 0.09 \\
\hline NQ_S5 & $2.5 Y R 4 / 6$ & non UM Niq (1.8 km of plant) & 0.19 & 0.70 & 4.59 & 88.12 & 153.43 & 2.01 & 0.30 & 0.03 & 0.05 & 0.07 & 0.10 \\
\hline NQ_S6 & $2.5 Y R 3 / 5$ & non UM Niq (5 km of plant) & 0.27 & 0.05 & 0.89 & 96.93 & 147.07 & 1.37 & 0.50 & 0.07 & 0.05 & 0.14 & 0.04 \\
\hline NQ_S7 & $2.5 Y R 3 / 2$ & non UM Niq (20 km of plant) & 1.89 & 0.72 & 0.71 & 108.89 & 200.17 & 1.70 & 0.57 & -0.19 & 0.13 & -0.37 & 0.25 \\
\hline
\end{tabular}




\section{Figure Captions}

Figure 1: Schematic view of the FeNi smelting and refining lines with the Ni content (adapted from Crundwell et al., 2011).

Figure 2: $\delta^{60} \mathrm{Ni}$ versus $\delta^{62} \mathrm{Ni}$ plot showing all the solid samples analyzed in this study $(\mathrm{n}=54)$ and the regression line (black line) relative to the equilibrium mass-dependent fractionation line (red line). The slope of the regression line (0.5134) is identical to that of the theoretical equilibrium fractionation law (0.5164) within uncertainty.

Figure 3: Average values of $\delta^{60} \mathrm{Ni}$ and $\delta^{62} \mathrm{Ni}$ for all samples (Ore: Feeding materiel $(\mathrm{n}=7)$, F:Fly ash $(n=10$, SS: Smelting Slag $(n=10)$, RS: Refined slag $(n=2)$ and FeNi $(n=2)$, UM soil $(n=20)$, non UM soil $(n=4)$. The error bar corresponds to SD.

Figure 4: Comparison of saprolitic and lateritic ore samples (modified from Ratié et al., 2015) with feeding material introduced in the metallurgical process and soil samples (this study).

Figure 5: Plot $\delta^{60} \mathrm{Ni}$ values vs molar ratio $\mathrm{Mg} / \mathrm{Al}$ for the UM soils and non-UM soils.

Figure 6: Variations in $\mathrm{Ni}$ isotopic composition (\%o) of published terrestrial samples (Cameron et al., 2009; Gall et al., 2012; Gueguen et al., 2013; Cameron \& Vance, 2014 ; Porter et al., 2014 ; Estrade et al., 2015; Ratié et al., 2015, Ventura et al., 2015) and byproduct metallurgical samples from our study (Fly ash, slag, FeNi and waste water). 


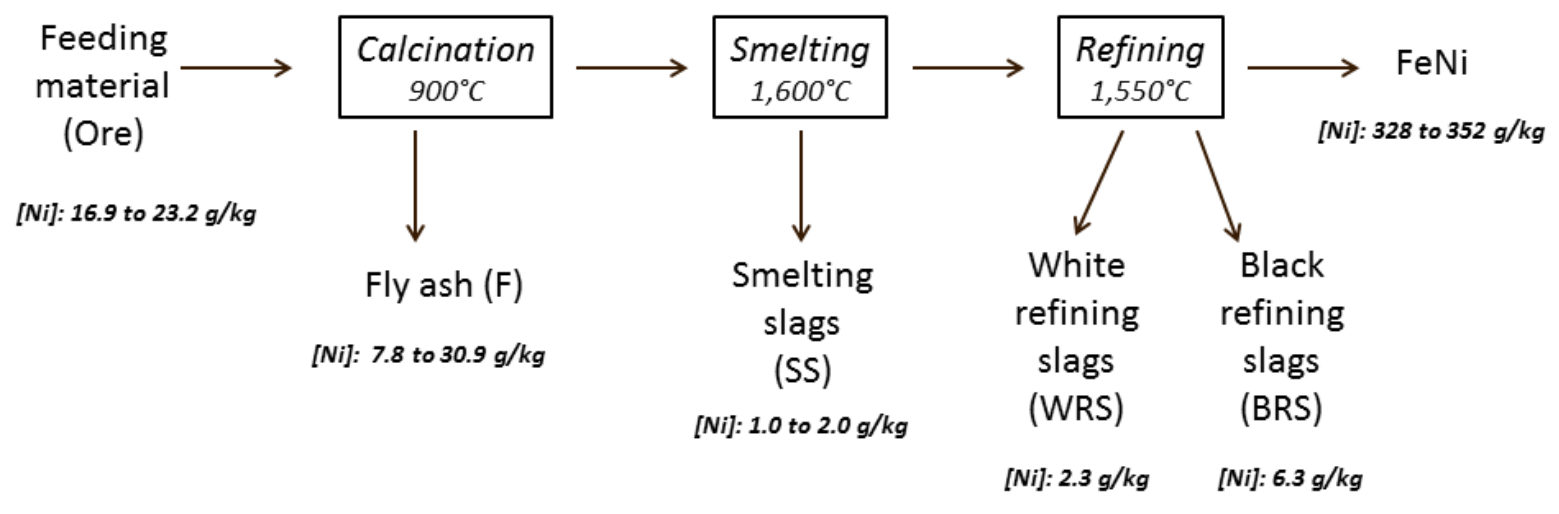

Figure 1 


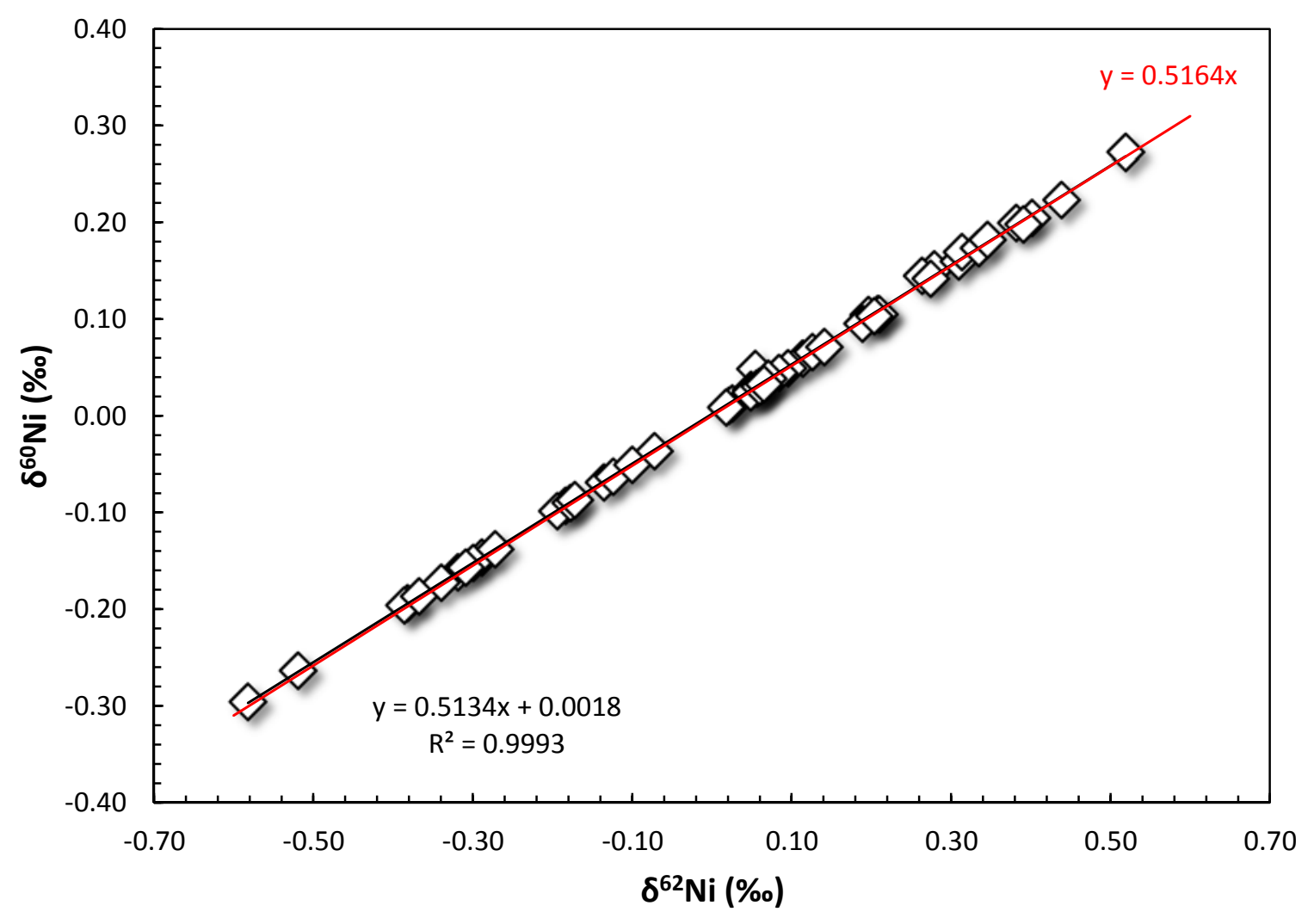

Figure 2 


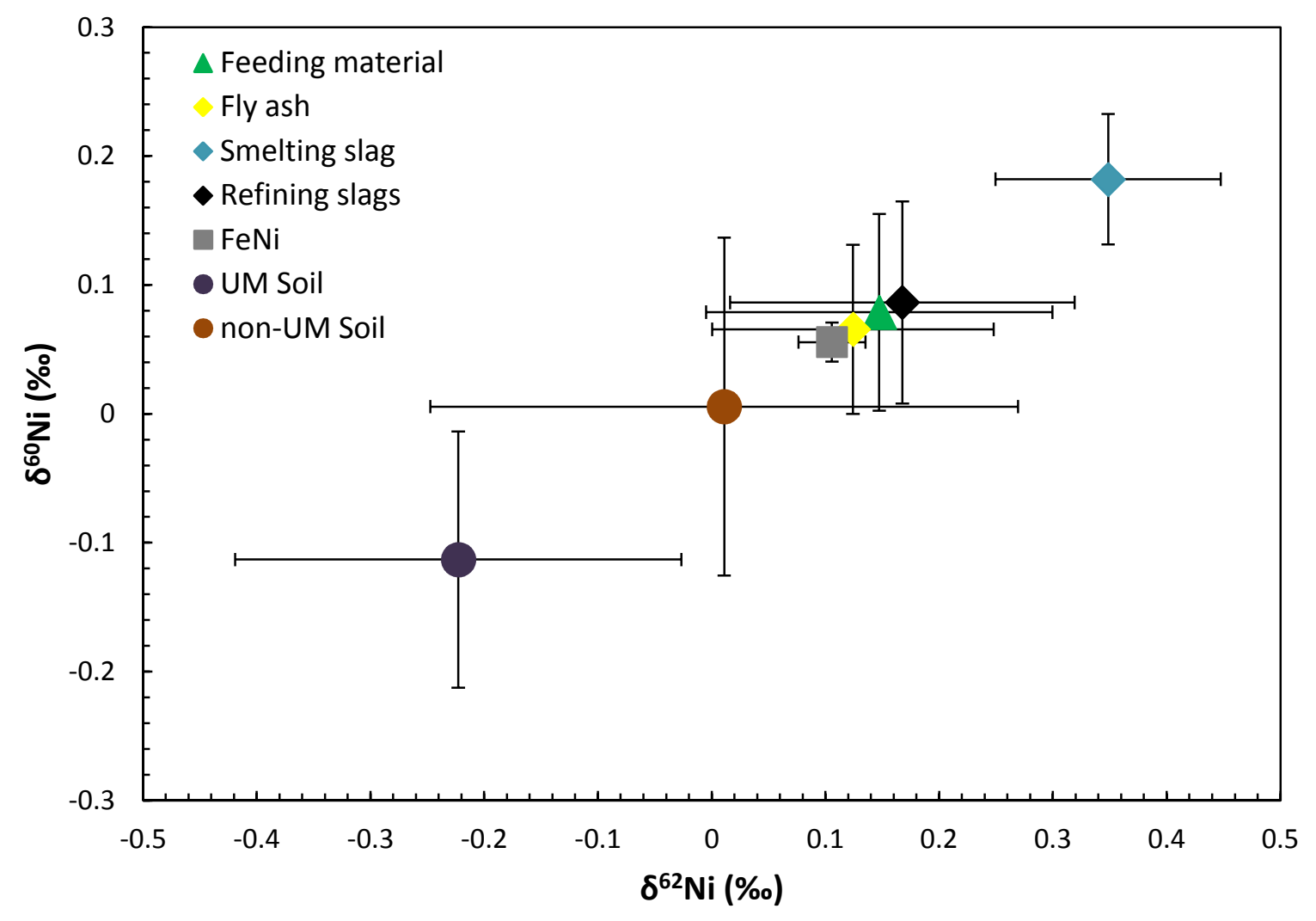

Figure 3 


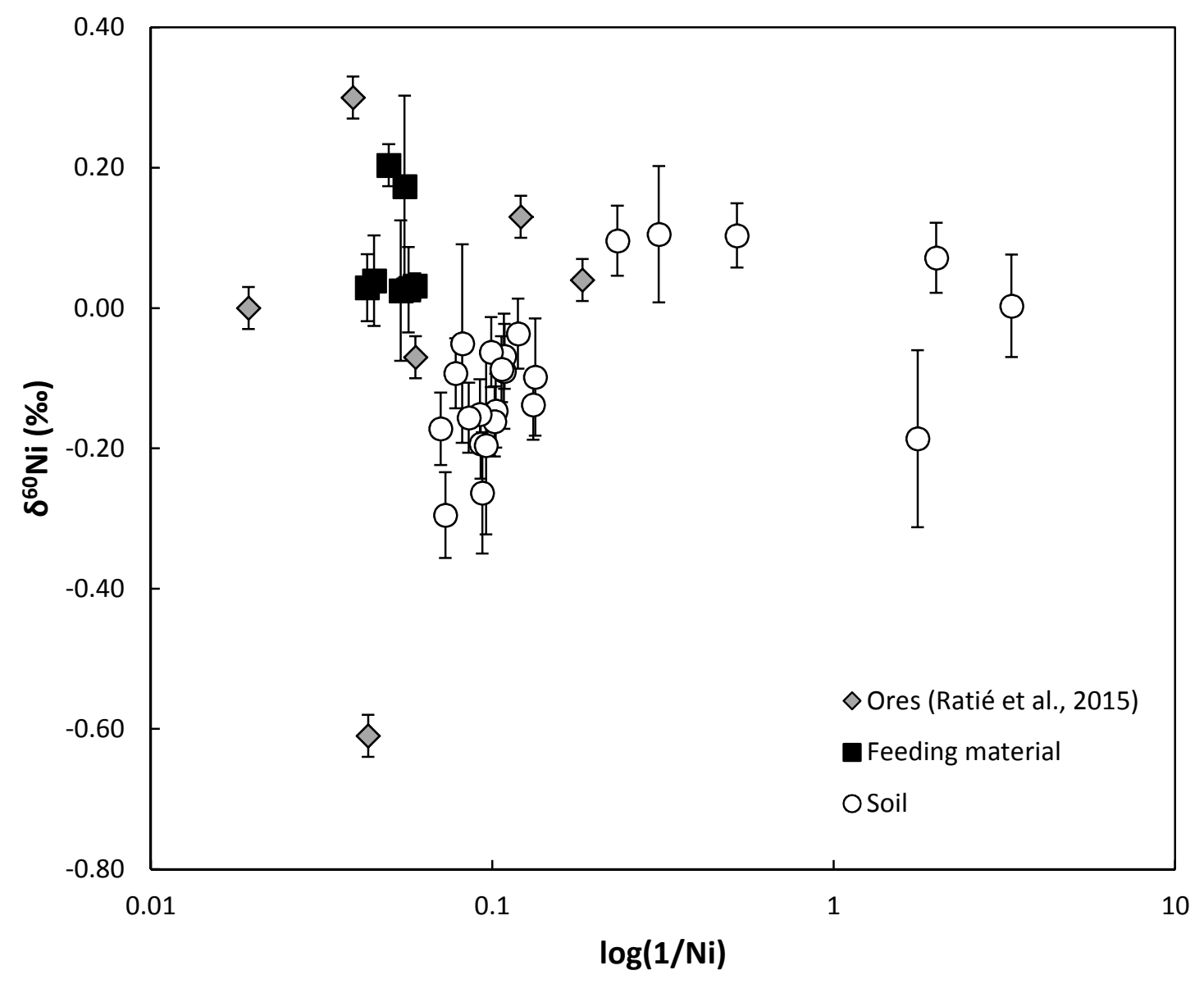

Figure 4 


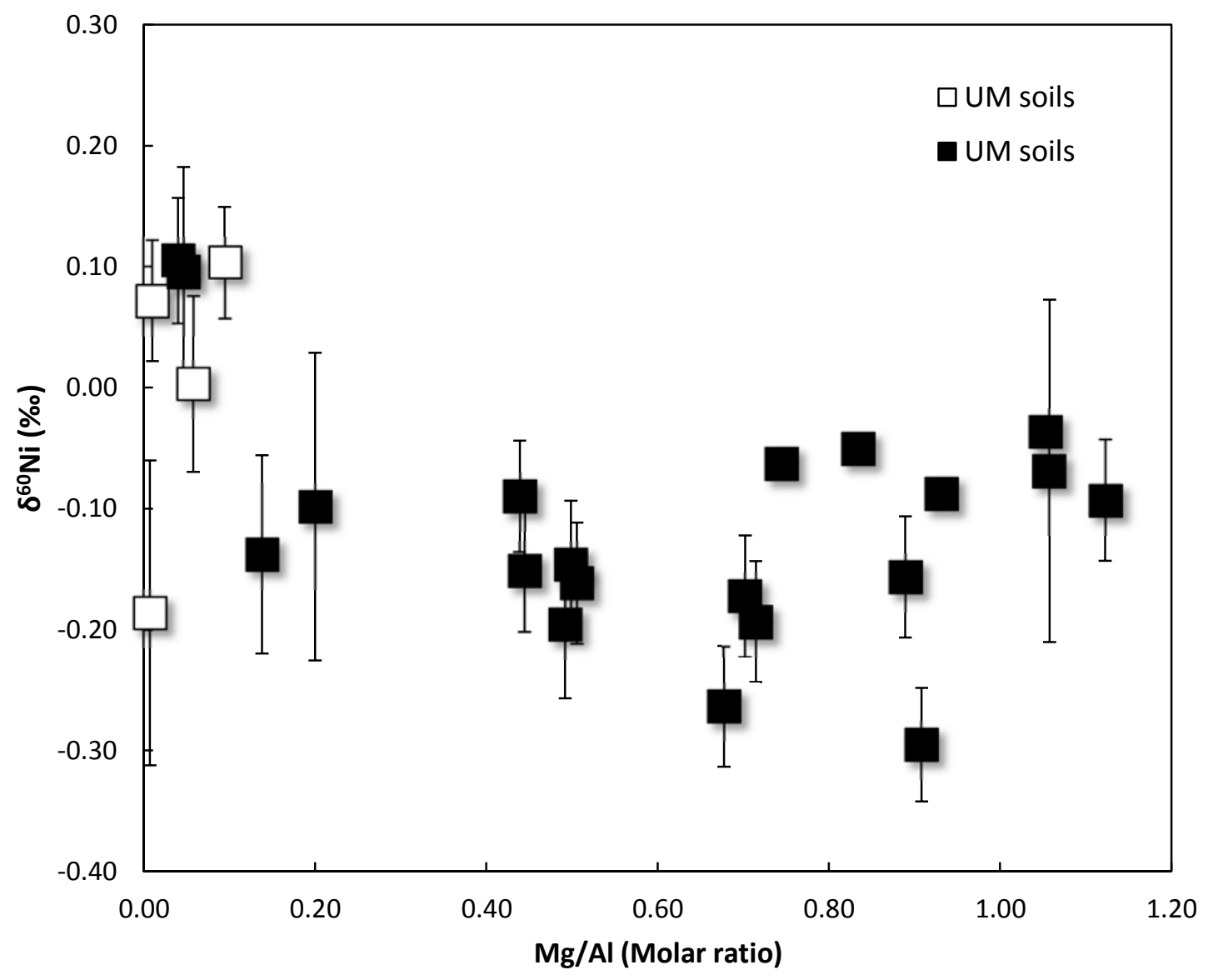

Figure 5 


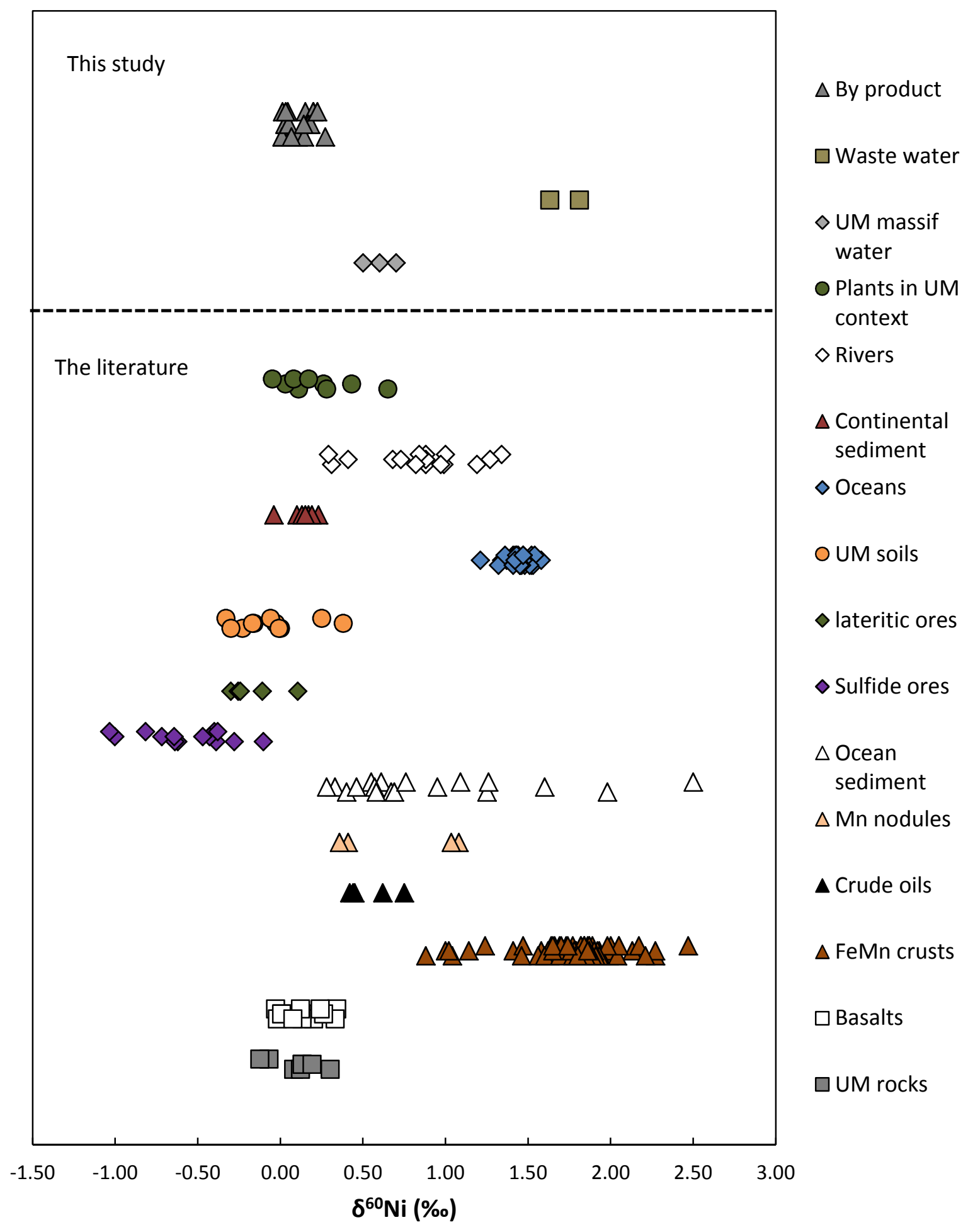

Figure 6 


\section{Supplementary Data 1}

\section{Leaching experiment}

To understand $\mathrm{Ni}$ isotope systematics during proton-promoted dissolution of $\mathrm{Ni}$ bearing metallurgical materials, $\mathrm{pH}$-stat leaching tests have been performed on slag and fly ash samples to simulate the release of Ni under acidic conditions. Slag and fly ash samples (SS3 and F2, respectively) were subjected to batch leaching at pH 3 using the approach based on pH-static leaching experiment to European standard CEN/TS 14997 (CEN, 2006). The leaching was carried out in duplicate at $20^{\circ} \mathrm{C}$. A mass of $1 \mathrm{~g}$ of solid was placed in $10 \mathrm{~mL}$ of MilliQ+ deionized water and $\mathrm{HNO}_{3}$ was added to adjust the $\mathrm{pH}$ to the value of 3. The slag sample was coarse-grained with $73 \%$ of particles between 0.5 and $2 \mathrm{~mm}$, while fly ash was fine-grained (75\% particles smaller than $1 \mathrm{~mm}$ ). Suspensions were continuously stirred for 48 hours, and leachates were filtered through $0.45 \mu \mathrm{m}$ membrane and analyzed for $\mathrm{Ni}$ concentration using either ICP-OES (Thermo Scientific iCAP 6500) or ICP-MS (Thermo Scientific X-series II). Nickel isotopes were measured in extracts and residual materials using the procedure described in the main text of the article.

\section{Evolution of Ni isotopic composition during leaching experiment}

Leaching experiments on fly ash sample (sample F2) released around 23\% of total Ni initially present in the sample, whereas only $6 \%$ of the total $\mathrm{Ni}$ was released from smelting slag (sample SS3). The $\delta^{60} \mathrm{Ni}$ values of the corresponding leachates $\left(\delta^{60} \mathrm{Ni}=0.12 \%\right.$ and $0.26 \%$ o for F2 and SS3 leachates, respectively, SI Fig. 1) are heavier than the solid residues, whose isotopic signatures are $\delta^{60} \mathrm{Ni}=-0.07 \%$ and $0.07 \%$ for $\mathrm{F} 2$ and $\mathrm{SS} 3$ residues, respectively.

\section{Nickel isotopic fractionation during proton-promoted weathering}

Leaching tests were performed to understand the consequences of acid weathering on $\mathrm{Ni}$ release (Ettler et al., 2015, submitted, SI for review only) and we report the associated potential fractionation. The Ni leached from both slag and fly ash samples is isotopically

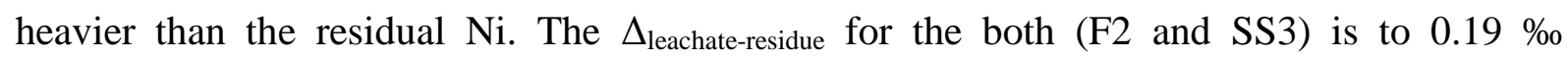


$\left(\delta^{60} \mathrm{Ni}_{\text {leachate }}-\delta^{60} \mathrm{Ni}_{\text {residue }}\right)$. This feature can be explained by the preferential dissolution of isotopically distinct phases during the incongruent dissolution of the samples, observed by Ettler et al. (submitted). These results can be compared to those obtained for the stagnant water collected in settling ponds in Niquelândia, where fly ash is stored for more than 20 years $\left(\delta^{60} \mathrm{Ni}\right.$ from 1.63 to $1.81 \%$ ).

The Ni-bearing phases weathered are mainly responsible of the $\delta^{60} \mathrm{Ni}$ heavier value in the leachates. In the slags, the small amount of $\mathrm{Ni}$ released $(6 \%)$ can be explained by the mineralogical composition dominated by amorphous phases, olivine, pyroxene and $\mathrm{FeNi}$ particles (Ettler et al., 2015, submitted). Amorphous phases are expected to be weathered more easily than the crystalline minerals; therefore the heavier pool observed in leachate would originate from $\mathrm{Ni}$ scavenged in the amorphous phases.

Fly ash presents a mineralogical composition more heterogeneous than slags, with the presence of magnesioferrite, talc, serpentine, amphibole, hematite, smectite, chlorite (Ettler et al., 2015, submitted). These minerals are typical of saprolitic and lateritic ores (Gleeson et al., 2004; Butt and Cluzel, 2013), which present a large variability in $\delta^{60} \mathrm{Ni}$ values (from $-0.61 \%$ o to $0.30 \%$; Gall et al., 2013; Ratié et al., 2015). The preferential dissolution of some of the Nibearing phases such as Ni-bearing serpentine-like phases, Ni-glass and olivine (Ettler et al., 2015, submitted) may explain the large proportion of Ni released (23\%). The isotopic composition of the leachate could indicate that these Ni-bearing phases are isotopically heavier than the residual phases. This could be confirmed by the measurements of Ni isotopes at a high spatial resolution, i.e. at the Ni-bearing phase scale. 


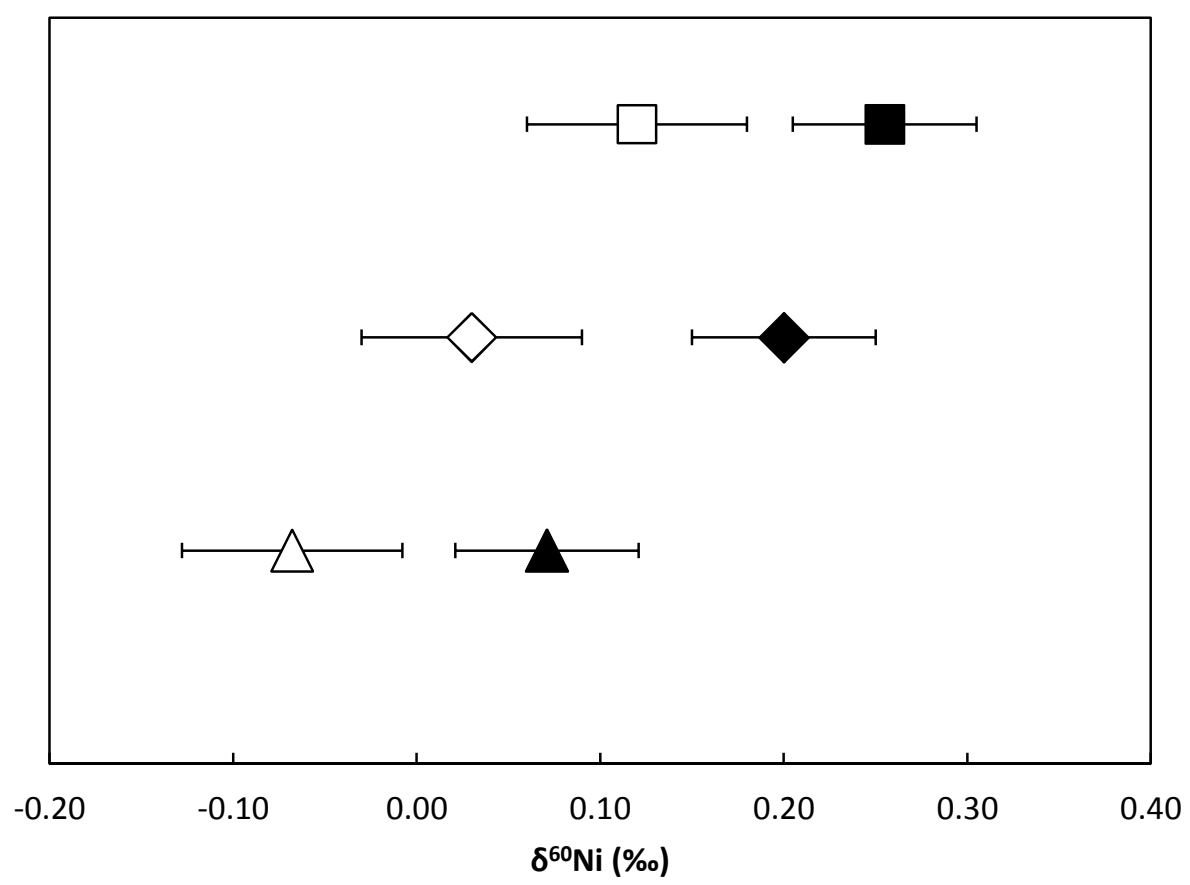

SI Figure 1: $\delta^{60} \mathrm{Ni}$ values for bulk samples (diamond) F2 (open symbols) and SS3 (closed symbols), their leaching fraction (square) and their residue (triangle) after controlled weathering. 